\title{
The Folklore of Shakespeare
}

\section{Henry B. Wheatley D.C.L.}

To cite this article: Henry B. Wheatley D.C.L. (1916) The Folklore of Shakespeare, Folklore, 27:4, 378-407, DOI: 10.1080/0015587X.1916.9718941

To link to this article: http://dx.doi.org/10.1080/0015587X.1916.9718941

$$
\text { 曲 Published online: } 01 \text { Feb } 2012 .
$$

Submit your article to this journal ㄴ

Цll Article views: 1

Q View related articles ¿ 


\section{THE FOLKLORE OF SHAKESPEARE.}

BY HENRY B. WHEATLEY, D.C.L.

\section{(Read at a Meeting of the Folklore Society, 21st June, 1916.)}

Tile folklore to be found in the works of Shakespeare forms a subject of the greatest interest, the illustration of which has by no means been exhausted. There is plenty of material for a systematic treatment which would present a handbook of great value, but much of this material does not lie on the surface, and requires research to discover allusions that are not at once manifest.1

Shakespeare was the first great folklorist who went to the very source of the learning of the folk. Others had done much, but he laid down the rules. He was a conscientious collector who did not invent, but saw the inherent beauty of the popular mythology, and then presented it to the world with all the gorgeousness and beauty which he alone could give it. This he did most completely in his presentation of the fairies, when he rejected the legends of antiquity related by learned authors, who generally confused the elves with the fiends and familiars of the sorcerers. Although at times Shakespeare made use of literary sources, such as

2 Mr. Thiselton Dyer's volume contains much useful information, and is helpful in elucidation of passages that have been unexplained or misunderstood. Three Notolets on Shakespeare (1865), by the late Mr. W. J. Thoms, the founder of our Soclety, and the inventor of its name, contains a charming essay on fairies. A chapter on "Folklore and Superatitions," by Prof. H. Littledale, in the great work, Shakespear's England, published by the Clarendon Press since the reading of this paper, is full of information presented with much freshness. 
the writings of Reginald Scot and Bishop Harsnet, and copied names of evil spirits from their pages, he still gave overwhelming prominence to "Elves of hills, brooks, standing lakes and groves" (Tempest, v. I).

Midsummer Night's Dream may be said to be the Bible of the elves, and what is omitted in the description of their habits there can be obtained from some of the other plays. Michael Drayton, in his beautiful poem Nymphidia (1627), follows Shakespeare in quite the same spirit, although he seems to have gone beyond him in inventing names for fairies.

Shakespeare's folklore may be broadly divided into eight classes: I. Fairy elves. 2. Nymphs and other classical spirits. 3. Devils and evil spirits. 4. Monsters. These are all supernatural beings. 5. Witches. 6. Magicians. 7. Ghosts and apparitions. 8. Dreams. Nos. 5 to 8 are connected with human life.

\section{Fairy Elves.}

Mortal or immortal. It is difficult to adopt a satisfactory nomenclature for these creatures of imagination. They have been called spirits, but although the word spirit is sometimes used to express the vital principle in man and animal, one feels reluctant to call a soulless being a spirit. The variant "sprite" therefore seems more appropriate in this case.

The fundamental difference between the folklore tradition and the literary treatment of fairies, mixed up with classical learning, is that in the latter case they are part of a system of evil spirits as opposed to the folklore assumption of mischievous soulless creatures.

There has been a battle royal among the learned on such matters as whether the fairies were mortal or. not. Human mortals are several times referred to in Midsummer Night's Dream, and this caused Steevens to opine that 
there were fairy mortals as well, and he adds, "Fairies were not human but they were subject to mortality. It appears from the romance of Sir Huon of Bordeaux that Oberon himself was mortal."

The cantankerous Ritson would have none of this. He writes: "A fairy addresses Bottom the weaver: 'Hail, mortal, hail!' which sufficiently shows she was not so herself." Further, Ritson says: "The fairies have already called themselves spirits, ghosts or shadows, and consequently they never died-a position at the same time of which there is every kind of proof that a fact can require."

Diminutive Creatures. Fairies were of a diminutive size, but could vary their size as suited them. They could make themselves visible or invisible as they wished. Ariel gives some indication of his stature when he sings :

"In a cowslip's bell I lie."

Their size is one of their chief characteristics, and Titania alludes to it in her address to her train of fairies (M.N.D. ii. 2. I).

Gambols. In dealing with the little people we must place their dancing in a prominent position, and not forget the fairy rings. We are told that the elves continued their gambols till sunrise :

"Puck. Fairy king, attend and mark;

I do hear the morning lark.

Oberon. Then, my queen, in silence sad,

Trip we after the night's shade."

The fairies of the Merry Wives are only sham fairies, but Anne Page, as queen, is allowed to explain the true ritual.

Houselold Duties. Cleanliness was highly prized by fairies, who pinched the sluts for their neglect. Belarius (Cymbeline, iii. 6 ) infers that fairies take no food when he says :

"But that it eats our victuals, I should think Here were a fairy." 
Imogen immediately appears to confess that she ate the food, but we have ample evidence that the fairies expected food as a reward for their household services. Puck remarks :

"And at our stamp here o'er and o'er one falls."

Johnson ridicules the effect of the stamp of an elf, and suggests the substitution of stump for stamp, but Oberon himself says further on:

"Come my queen, take hand with me, And rock the ground whereon these sleepers be."

Changelings. A clangeling was the cause of the quarrel between Oberon and Titania, and the various references in the plays to the cruel robbery of infants by the elves seem natural when we are living in an atmosphere of fairies. When we find Henry IV., intent on State affairs, expressing his bitter disappointment at his son's profligate behaviour with a wish that he was a changeling, we see how deeply the poet was charged with knowledge of the superstitions of the folk that such a thought should have occurred to him:

"O that it could be prov'd

That some night-tripping fairy had exchang'd In cradle-clothes our children where they lay, And call'd mine Percy, his Plantagenet !

Then would I have his Harry, and he mine; But let him from my thoughts."

I Henry IV. i. 1. 87.

King and Queen of Fairies. In turning to the chief characters among the fairies, Oberon and Titania come first from pride of place. Shakespeare lavished upon them the richest of his wondrous verse, and they interest us in all they say or do, but they are altogether too regal to be representative fairies. Oberon by right of fame was a true king, and his renown was widespread, but Titania is the poet's own creation, and her name was taken from a classic 
source. The queen of popular tradition was Mab, and she was not neglected by Shakespeare, who makes Mercutio describe her with so much minuteness and vividness. She is quite unlike Titania, and is presented as a sort of feminine Puck, as full of mischief as he was.

Puck and Ariel. The two outstanding fairies who were painted with loving care by Shakespeare are Puck and Ariel, and a wonderful pair they stand before us.

Puck was the generic name for an elf, and his creator has gathered together all the elfish characteristics known to him, and welded them together to form the fairy hero of Midsummer Night's Dream. There are many pictorial illustrations to Shakespeare's plays, but few of them are successful. There is, however, one that is perfect: Reynolds's Puck is an immortal portrait of our "gentle Puck," our "sweet Puck"-Shakespeare's Puck. Puck is the concentrated essence of elfdom, but Ariel is a fresh creation from Shakespeare's heart and brain. Both are fairies (soulless beings), but the circumstances that formed them have been widely different. Puck is of the earthearthly, but Ariel is of the air-airy. Puck is the attendant upon Oberon, and in constant personal intercourse with fairies, but Ariel has no fairy companions, only certain sprites who attend him and do his biddings. He is the servant of the magician Prospero, who rules him severely but loves him. This is evident from such expressions as "my brave spirit," " my bird," " my tricksy spirit," " my industrious servant," "my Ariel," "my quaint Ariel," " my fine Ariel," "my dainty Ariel," "my delicate Ariel." Ariel understands human feelings, though by the disability of his nature he is unable to rise to them. He tells Prospero that his affections would go out to others were he human: Some of the most exquisite songs Shakespeare ever wrote were sung by this beautiful ethereal being, who remains unsurpassed in the realms of fairyland. 
2. Nymphs, Naiads, Nereids, Mermaids.

These form a class of supernatural beings which cannot well be explained, though they have formed the stock-intrade of poets for many ages, as most of these poets held different views respecting them. They are described in classical dictionaries as goddesses and as inferior divinities. All are alluded to by Shakespeare, but they have little to do with genuine folklore, although from one point of view they are in touch with Ariel. There are nymphs of the hills, forests, and caves, of springs, streams, and rivers ; and Ariel sings of "Sea-nymphs [who] hourly ring his knell" (Tempest, i. 2. 402). The sprite Iris, when she sings "You nymphs call'd naiads of the wandering brooks" (Tempest, iv. I28), is quite in accord with classical usage.

Nereids were nymphs of the sea, daughters of Nereus. They are described as attendant on Cleopatra:

"Her gentlewomen, like the Nereids, So many mermaids."

Antony and Cleo. ii. 2. 211.

The nereids were not mermaids, for a piece of statuary in the Naples Museum shows one borne along by a triton, and she has legs like an ordinary woman.

The sea captain tells Viola of her brother Sebastian :

"Where, like Arion on the dolphin's back,

I saw him hold acquaintance with the waves

So long as I could see." Twelfth Night, i. 2. I5.

This refers to the story of Arion, the Greek musician, who was saved from drowning by dolphins drawn to him by his sweet singing. One of them, taking him on his back, carried him safe to land.

In Midsummer Night's Dream (i. 2. 15) Oberon says :

"Since once I sat upon a promontory,

And heard a mermaid, on a dolphin's back, Uttering such dulcet and harmonious breath That the rude sea grew civil at her song." 
A mermaid might have worked upon the feelings of a dolphin by the sweetness of her yoice, siren as she was, but one would suppose a mermaid could take care of herself on the sea without the help of a dolphin.

Both these references seem to have been suggested by Gascoigne's Princely Pleasures at Kenilworth in 1575. A triton, in likeness of a mermaid, came towards the Queen to declare the woeful distress of the Lady of the Lake; also Proteus appeared sitting on a dolphin's back, and then assumed the character of Arion.

\section{Devils and Evil Spirits.}

The literature of evil spirits is a considerable one, and Shakespeare has many references to these devils mostly taken from the works of Reginald Scot and Bishop Harsnet. One of the particularities of the old writers on Demonology was to catalogue the colours of the spirits. Scot specially mentions white, black, grey, and red spirits. Some less instructed writers refer to blue and green spirits, but these colours were not acknowledged by the chief authorities.

In Macbeth (iv. 1.), when Hecate calls for song, the only stage direction in the first folio is "Music and a song, 'Black spirits'," etc. In Davenant's version of Macbeth (1674) the song is printed in full from Middleton's The Witch (Act v. sc. 2), as follows :

"Black spirits and white,

Red spirits and gray,

Mingle, mingle, mingle,

You that mingle may."

Dr. Aldis Wright was mistaken when he said that Davenant substituted 'Blue' for 'Red' in the second line. Rowe however did print 'Blue.'

Falstaff says: "That same mad fellow of the north, Percy, and he of Wales, that gave Amaimon the bastinado" 
(I Henry IV. ii. 4. 370). This was one of the four chief devils described by Scot (Discoverie of Witcheraft, 1584, Book 15, chap. 3). He was king of the east. The other three were Gorson, king of the south ; Zimimar, king of the north; and Goap, king of the west. These, however, are not mentioned by Shakespeare. Scot gives the hours when these devils may be "restrained from dooing of hurt." He also gives a long list of important devils : "Marbas alias Barbas is a great President, and appeareth in the forme of a mighty lion." This devil is represented by Barbason in Henry V. (ii. I. 57), where Nym says : "I am not Barbason, you cannot conjure me." Page also mentions him (Merry Wives, ii. 2. 3II) when he cries out in anger, "Amaimon sounds well, Lucifer well, Barbason well, yet they are devils' additions, the names of fiends."

Cerberus, "a valiant marquesse."

Scot's Discoverie.

"Great Hercules is presented by this imp

Whose club kill'd Cerberus." L.L.L. v. 2. 593.

King Lear contains the names of many "foul fiends," and also of some who were not fiends at all, as Flibbertigibbet, who was a sprite and companion of the elves, and probably Hobbididance, whose name is like Hobgoblin. Most of these names occur in Harsnet's Declaration of Popish Impostures, 1603. Edgar says :

"Five fiends have been in poor Tom at once; of lust, as Obidicut ; Hobbididance, prince of dumbness ; Mahu, of stealing ; Modo, of murder; and Flibbertigibbet, of mopping and mowing !" iv. x. 62 .

"Peace, Smulkin; peace, thou fiend!" iii. 4. 146.

"The Prince of Darkness is a gentleman :

Modo he's call'd, and Mahu."

iii. 4. 148.

"Frateretto calls me; and tells me Nero is an angler in the lake of darkness."

iii. 6. 7 . 
Demon is only used once by Shakespeare as a synonym of devil :

"If that same demon that hath gull'd thee thus Should with his lion gait walk the whole world,' He might return to vasty Tartar [Tartarus] back."

$$
\text { Henry V. ii. 2. } 121 .
$$

To him the demon was the genius or good angel, and the good or evil familiar spirit.

"Ferdinand to Prospero. the strong'st suggestion

Our worser genius can, shall never melt

Mine honour into lust."

Tempest, iv. 1. 27.

"Soothsayer to Antony. Thy demon, that's thy spirit which keeps thee, is

Noble, courageous, high, unmatchable,

Where Caesar's is not; but near him thy angel

Becomes a fear, as being o'erpower'd, therefore

Make space enough between you."

Antony and Cleo. ii. 3. 19.

\section{Monsters.}

The word Sagittary, meaning a centaur who shot with a bow and was horrible to look at, is used in two senses by Shakespeare, which has confused some of the commentators. Agamemnon, referring to the help given by this monster to the Trojans, says :

Appals our numbers."

"the dreadful Sagittary

Troilus and Cressida, v. 5. 14.

The other reference is to the arsenal in Venice, known as the Sagittary from the figure of the archer monster over the entrance.

Iago says :

"Lead to the Sagittary the raised search."

Othello, i. I. 159. 
Othello, in a later scene, says :

"I do beseech you,

Send for the lady to the Sagittary." i. 3. 115.

The name is the same as that of the bowmen in the Roman army, known as Sagittarii.

The three Gorgons, the sight of whose snaky hairs turned beholders to stone, have a passing mention:

"Though he be painted one way like a Gorgon,

The other way's a Man."

Antony and Cloopatra, ii. 5. 116.

Medusa was mortal; that was proved when Perseus cut off her head. The other two, not having a similar misfortune, were supposed to be immortal.

The Furies are referred to several times by Shakespeare. Até, the goddess of mischief, was connected with them, but they are often treated as something more than monsters, and appear as avengers of wrong.

"Approach, ye Furies fell." MK.N.D. v. 289.

"Seize on him, Furies, take him into torment."

Richard III. i. 4. 37.

The Harpy was a monster with the face of a woman and the body of a bird of prey. Prospero says:

"Bravely the figure of this harpy hast thou

Performed, my Ariel." "Tempest, iii. 3. 83.

Benedick wildly likens Beatrice to a harpy and also to Até.

\section{Witches.}

I have placed the heading of witches here because the subject contains a line of demarcation between supernatural and human beings. The witches of Macbeth (the weird sisters) are uncanny creatures, belonging to the supernatural class, connected with the Scandinavian Norns. The ordinary witch was a human creature in league with the devil. The witches were mostly old ill-favoured women, but some 
young women were often denounced by enemies, and suffered a cruel death. Charles Lamb says of The Witch of Edmonton, by Rowley, Decker \& Ford: "Mother Sawyer differs from the hags of Middleton or Shakespeare. She is the plain, traditional, old woman witch of our ancestors : poor, deformed, and ignorant; the terror of villages, herself amenable to justice. That should be a hardy Sheriff, with the power of a county at his heels, that would lay hands upon the Weird Sisters."

It is only necessary to indicate a few points relating to witches, as the subject is too vast for incidental treatment. It is difficult to realise that human nature in a civilised society could sink to the execution of such frightful cruelties as are credibly related.

The literature of the subject is largely contained in two books: The Discovery of IVitchcraft, by Reginald Scot (1584), and $A$ Declaration of Egregions Popish Impostures under the pretence of Casting out Devils, practised by Edinunds, alias Weston, a Jesuit, and divers Roman Priests, his wicked assistants (1603), by Samuel Harsnet, Bishop of Chichester, and afterwards Archbishop of York.

These two authors throw much light upon the subject, and have been found to be valuable illustrators of many passages in Shakespeare's plays. They are both unfair to the Roman Catholics, because they make then responsible for superstitions equally believed in by Protestants of the time,

Dr. Brinsley Nicholson reprinted Scot's work in 1886, and in his dedication to Prince Leopold, Duke of Albany, he refers as follows to the author: "This work of an Elizabethan Englishman... whose honesty, intelligence and compassion fought against the cruel superstition and ignorance of .his age." Scot, however, built up his case with an immense amount of information which shows a considerable leaning towards credulity.

Harsnet was more authoritative than Scot, for he printed 
the copies of the several "Examinations and confessions of the parties pretended to be possessed and dispossessed by Weston the Jesuit and his adherents; set down word for word as they were taken upon oath before her Maiesties Commissioners for Causes Ecclesiasticall." The Bishop's book contains a full account of the various cases mentioned in the above. Much ill-considered controversy has taken place over the supposed connection of Shakespeare's witches with those introduced by Middleton in his play of The Witch. Lamb's criticism is most illuminating, and cannot be improved upon. Hazlitt was content to quote it in his Characters of Shakespeare's Plays, 1817, without any addition of his own :

"Though some resemblance may be traced between the charms in Macbet/2 and the incantations in this play, which is supposed to have preceded it, this coincidence will not detract much from the originality of Shakespeare. His witches are distinguished from the witches of Middleton by essential differences. These are creatures to whom man or woman plotting some dire mischief might resort for occasional consultation. Those originate deeds of blood, and begin bad impulses to men. From the moment that their eyes first meet with Macbeth's he is spell-bound. That meeting sways his destiny. He can never break the fascination. These witches can hurt the body, those have power over the soul."

Lamb was mistaken as to the date of the publication of The Witch. The play was printed for the first time in 1778. The original MS. is in the Bodleian Library among Malone's books. Much of the confusion as to the witches of Shakespeare and Middleton has arisen from Davenant having used some songs from The Witch in the altered Macbeth attributed to him, and published in 1674, six years after his death. It may be noted that Middleton, like Shakespeare, obtained the names of his devils from Scot's Discovery. 
The qualities of the witch were very varied, and Shakespeare indicates her power and its limitations. Witches afflicted people with melancholy fits and loss of flesh.

"Weary sev'n-nights, nine times nine

Shall he dwindle, peak and pine" Macbeth, i. 3.

Or they exhausted the moisture of the body :

"I will drain him dry as hay."

They had power over winds and tempests, but sometimes these powers were circumscribed :

"Though his bark cannot be lost,

Yet it shall be tempest-toss'd."

They had power to sell a wind, and sometimes they made a free gift of one. The second witch says :

"I'll give thee a wind."

Perhaps their greatest power was that of controlling the moon. Prospero says of Caliban:

"His mother was a witch

That could control the moon." Tempest, v. x.

In the first act of this same play Gonzalo said :

"You are gentlemen of brave mettle; you would lift the moon out of her "sphere."

Douce refers us to a note in Adlington's translation of Apuleius on this same subject: "Witches in old time were supposed to be of such power that they could put downe the moone by their inchauntment." Douce quotes largely from the Latin poets on this point, and these myths are intimately connected with widespread beliefs relating to eclipses and other natural phenomena. The witch's power of vanishing at will is specially referred to in Macbeth. When Banquo inquires respecting this disappearance, where the witches have gone, Macbeth answers :

"Into the air; and what seem'd corporal melted As breath into the wind." 
On the other side, at cockcrow the witch's power ceased. Thus Marcellus speaks:

"No fairy takes, nor witch hath power to charm, So hallow'd and so gracious is the tinee." Hamlet, i. r.

He that could draw blood from a witch was free:

" Devil, or devil's dam, I'll conjure thee:

Blood will I draw on thee; thou art a witch."

I Henry VI. i. 5.6.

The "Wise Woman," a woman skilled in hidden arts, fortune-telling, palmistry, etc., is often mentioned in the literature of the time, and is very nearly allied to the witch. She is mentioned in Twelfth Night (iii. 4), and the Wise Woman of Brentford in Merry Wives is also called in the same play " the witch of Brentford."

\section{Magicians.}

Magicians and sorcerers are so mixed up with supernatural devilry that it would be going over ground already paced in the previous divisions to describe them here, but Prospero, the great magician of Shakespeare, is so distinct a character that he cannot be entirely overlooked in the catalogue of folklore personages.

He was a magician with his familiar spirits, and his relations with one of these-the high-spirited Ariel-have already been referred to. Unlike the ordinary magician, his actions were beneficent and not evil. When, however, the time was come for giving up his occupation he was not loath to retire. His superhuman powers had their source in his garments, in his books of magic, and in his staff. These, therefore, he decided to destroy:

"Pluck ny magic garments from me,-so;

Lie there my art."

He thus commands. His magic book must be drowned:

" Deeper than did ever plummet sound I'll drown my book" 
The staff, by which he could make his opponent's weapon drop, was broken and buried :

"Bury it certain fathoms in the earth."

Prospero is relieved when he has abjured his magic, as he says, in the Epilogue:

"Now my charms are all o'erthrown, And what strength I have's mine own."

. Owen Glendower (1 Henry IV. iii. 1), like Prospero, claims to be an enchanter, but Hotspur denies his claim.

" Glen. I can call spirits from the vasty deep.

Why, I can teach you, cousin, to command the devil.

Hotspur. And I can teach thee, cor, to shame the devil

By telling truth."

\section{Ghosts and Apparitions.}

A mine of information respecting the folklore of ghosts is to be found in the plays of Shakespeare. The apparitions of the most world-wide fame are those of Julius Caesar, who appeared to Brutus at Philippi (J.C. iv. 3), and Hamlet's father.

Pompey, in Antony and Cleopatra (ii. 6), refers to Julius Caesar, "who the good Brutus ghosted." This is an uncommon verb used also by Burton in his Anatomy of Melancholy.

Hamlet's father was committed to Purgatory, and forbidden to tell the secrets of his prison-house; but he had sufficient to tell of his "foul murder" and of his hard lot until his death had been avenged:

" Doom'd for a certain term to walk the night, And for the day, confin'd to fast in fires Till the foul crimes, done in my days of nature, Are burn'd and purg'd away." 
He complained that he was "cut off in the blossoms of his sins, unhousel'd, disappointed, unanel'd." That is, he had not received the eucharist or extreme unction. Other spirits in the same case remained wanderers if they had not received funeral rites. We find note of unlaid ghosts in Cymbeline, and of enclosed ghosts, who are let free when the graves fly open:

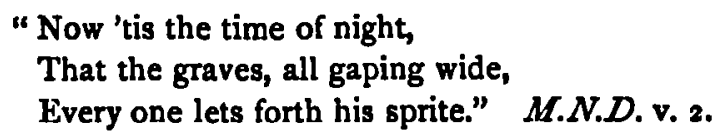

Calphurnia, when she warns Caesar of his danger, tells him that aforetime she never gave way to any fear or superstition, "yet now they fright me."

“The graves have yawn'd, and yielded up their dead, And ghosts did shriek and squeal about the streets."

Julius Caesar, ii. 2.

Horatio, referring to these portents, uses almost the same words :

"In the most high and palmy state of Rome, A little ere the mightiest Julius fell, The graves stood tenantless, and the sheeted dead Did squeak and gibber in the Roman street."

Hamlet, i. $\mathbf{~ . ~}$

These horrors seem to appeal to Shakespeare's imagination, and he frequently referred to them. The ghost of Hamlet's father is sometimes seen by all on the stage, and sometimes only by his son, but he will address no one but Hamlet. Banquo's ghost is seen only by Macbeth, who asks him to appear in any horrible form rather than as a ghost:

"Take any shape than that." . Macbeth, iii. 4.

. Ghosts disliked light, so Brutus's taper burned dim when Caesar's ghost appeared.

It was also a popular belief that the candle burned blue when an evil spirit was in the house. Richard III., in his 
tent on Bosworth field, after he had been visited by a whole army of ghosts of those enemies he had destroyed ${ }_{2}$ noticed that "the lights burn blue" (Richard III. v. 3).

Shakespeare uses the words exorcism, exorciser, and exorcist. Respecting this use, Monck Mason remarks : "The word exorcise and its derivatives are used by Shakespeare in an uncommon sense. In all other writers it means to lay spirits, but in these plays it invariably means to raise them.

Ligarius says :

"Thou like an exorcist has conjured up My mortified spirit." Julius Caesar, ii. I.

In the funeral song in Cymbeline (iv. 2), which forms a dialogue between Guiderius and Arviragus after the supposed obsequies of Fidele (Imogen), we read :

"Gui. No exorciser harm thee!

Aro. Nor no witchcraft charm thee!

Gwi. Ghost unlaid forbear thee !

Aro. Nothing ill come near thee!"

In All's Well that Ends Well (v. 3) the King uses the word exorcist in a strange sense :

"Is there no exorcist

Beguiles the truer oftice of mine eyes?

Is't real, that I see?"

Johnson notes: “This word is used, not very properly, for enchanter."

Monck Mason is not entirely correct in his statement, as in two instances Shakespeare's exorcist both raises and lays a spirit.

Roger. Bolingbroke in 2 Heinry VI. (i. 4) is styled in the Dramatis Personæe a conjuror, who acts with two priests named Hume and Southwell. He asks if the Duchess of Gloster will "behold and hear our exorcisms." He calls on Asmath and threatens, "till thou speak, 
thou shalt not pass from thence," and afterwards he dismisses him:

"Descend to darkness and the burning lake:

False fiend, avoid!"

In Macbeth (iv. I) the apparition of an armed head raised by the witches' power, after having delivered his prophecy to Macbeth cries, "Dismiss me;-enough," and then descends.

\section{Drcams.}

When the people believed in dreams as portents a great dread of them naturally existed. Malicious spirits tormented their victims, but the sleepers were guarded by the possession of relics and amulets of various kinds.

Imogen prays to be relieved "from fairies and the tempters of the night " (Cymbeline, ii. 2), and Banquo cries out : "Restrain in me the cursed thoughts that Nature Gives way to in repose."

Macbeth, ii. I.

Shylock thought that when he dreamed of his money misfortune would overtake him :

"There's some ill a-brewing towards my rest

For I did dream of money bags to-night."

Andromache says:

Merchant, ii. 5.

"My dreams will sure prove ominous to the day."

Troilus and Cressida, v. 3.

Mercutio makes merry over the dreams which Queen Mab mischievously put into the heads of those she visited and over the consequences thereof (Romeo and Juliet, i. 4).

Romeo himself rejoices over the good he hopes to attain by the reality of his dreams :

"My dreams presage some joyful news at hand."

"I dreamt my lady came and found me dead, (Strange dream I that gives a dead man leave to think,) And breath'd such life with kisses, in my lips, That I reviv'd, and was ah emperor." $R$. and J. v. I. 


\section{The Calendar.}

The subject may be concluded by some notice of Shakespeare's Folk-lore of the various holy and famous days of the year.

Bottom is very anxious for a calendar, and cries :

"Look in the calendar, find out moonshine."

$$
\text { M.N.D. iii. 1. 54. }
$$

Richard III. asks for a calendar, demanding :

"Who saw the sun to-day?"

Macbeth wishes

K. Richard III. v. 3. 276.

"this pernicious hour

Stand aye accursed in the calendar."

Macbeth, iv. i. 133 .

" "Tis a lucky day, boy, and we'll do good deeds on it."

Winter's Tale, Act iii. Sc. iii.

Brutus asks :

"Is not to-morrow, boy, the ides of March ?"

Lucius. I know not, sir.

Brutus. Look in the calendar, and bring me word."

The most important of these references is in King Jolnn (iii. i. 83):

"Consiance. A wicked day and not a holy day I

What hath this day deserv'd? what hath it done,

That it in golden letters should be set

Among the high tides [time] in the calendar?

Nay, rather turn this day out of the week;

This day of shame, oppression, perjury."

In the various plays all the months, with the exception of the autumn ones (September, October and November) are specially alluded to. Shakespeare has also written something on most of the famous days, but many of these he has passed over lightly. 


\section{January.}

Perdita refers to "blasts of January" " that blow you through and through " (Winter's Tale, iv. 4. III).

"Leonato. You will never run mad, niece. Beatrice. No, not till a hot January."

$$
\text { Much Ado, i. т. } 94 .
$$

1. Falstaff alludes with satiric touch to the once vast system of presentations on New Year's day when he says "I'll have my brains ta'en out and buttered, and give them to a dog for a New Year's gift" (Merry Wives, iii. 5).

6. Twelfth Night was the title Shakespeare gave to one of his plays, but it has nothing more to do with the festival than its original presentation on that anniversary. Pepys saw the comedy on Twelfth Night, 1663, but he thought it was "a silly play and not related at all to name or day."

\section{February.}

" Don Pedro. Good morrow, Benedick. Why, what's the matter That you have such a February face, So full of frost, of storm, and cloudiness ?"

$$
\text { Much Ado, v. 4. 4r. }
$$

I4 Allusions to St. Valentine's day will be found both in Hamlet and Midsummer Night's Dream.

The reason for choosing St. Valentine as the patron of lovers has not come down to us, further than by assuming that the date marked the period for the mating of birds. The supposition that, being famous for the virtues of love and charity, he was properly chosen to take charge of lovers appears a somewhat weak one.

Ophelia sings :

“To-morrow is St. Valentine's day,

All in the morning betime,

And I a maid at your window

To be your valentine."

$2 \mathrm{C}$

Hamlet, iv. 5 . 
Duke Theseus says :

"Good morrow, friends, St. Valentine is past ;

Begin these birds but to couple now."

This observation was very inappropriate, as he was speaking at midsummer; but shortly before he had made an equally out-of-date remark when he suggested that the lovers who had been found asleep

\section{"Rose up early to observe}

The rite of May."

These points have induced some critics to affirm that the dream really occurred on the eve of May Day, and that the title of Midsummer Night merely referred to the time of production, as it does in Twelfth Night and Winter's Tale.

\section{Marck.}

Perdita. ... daffodils, That come before the swallow dares, and take The winds of March with beauty.... Winter's Tale, iv. 3 .

Hotspur. No more, no more : worse than the sun in March, This praise doth nourish agues.... I Henry IV. iv. x. $1 \mathrm{I} x$.

I. St. David's Day. The day observed in honour of the patron saint of Wales has long been associated with the wearing of the leek in the hat as a national emblem.

The irascible Fluellen, in his talk with Henry V., infers that the custom originated at the battle of Crecy in 1346, but tradition affirms that St. David himself ordered the Welsh to wear a leek in their hats to distinguish them from Saxons. Fluellen tells the King :

"I do believe your Majesty takes no scorn to wear the leek upon Saint Tavy's Day,"

to which Henry replies :

"I wear it for a memorable honour,

For I am Welsh, you know, good countryman." King Henry $V$. iv. 7. 
In the next act Gower asks Fluellen :

" Why wear you your leek to-day?

Saint Davy's Day is past."

It was long past, for the battle of Agincourt was fought on October 25th. Shakespeare does not appear to have remembered the date of St. David's Day. It is not clear why the leek should have been worn at Crecy, as the battle was fought on August 26th. Perhaps it was worn to mark the large number of Welshmen present, which was estimated to be one thousand.

17. St. Patrick's Day.-Hamlet swears by St. Patrick (i. 5. 136), and some commentators have supposed that Richard II. alluded to the tradition that St. Patrick freed Ireland from venomous reptiles of all kinds when he said:

"Now for our Irish wars:

We must supplant those rough rug-headed kerns

Which live like venom, where no venom else,

But only they, hath privilege to live." ii. 1. 155.

\section{April.}

- Proteus. $\mathrm{O}$ how this spring of love resembleth

The uncertain glory of an April day, Which now shows all the beauty of the sun, And by and by a cloud takes all away."

Tivo Gentlemen, ii. I. 84

23. St. George's Day. The great national festival of England's patron saint has been increased in importance by its recognition as the anniversary of the death day of Shakespeare himself. " God and St. George," "St. George; forward," and "Upon them, St. George," were conquering battle-cries. Henry V. calls to his men :

"Cry 'God for Harry, England, and St. George !' " 
The valiant Talbot says :

"God and St. George, Talbot and England's right,

Prosper our colours in the dangerous fight !"

I Henry VI. iv. 2. 55.

The Duke of Bedford, Regent of France, while lamenting the death of Henry V., will have no lamentations on the battle-field, and says :

"Bonfires in France forthwith I am to make,

To keep our great St. George's feast withal."

I Henry VI. i. I. I54.

The bastard Faulconbridge alludes to the popularity of St. George and the dragon as a tavern sign :

"Saint George, that swing'd the dragon, and e'er since Sits on his horse back at mine hostess' door,

Teach us some fence !"

King John, ii. 288.

\section{May.}

The most popular month among the poets. The song beginning :

"As it fell upon a day

In the merry month of May,"

has been attributed to Shakespeare, from having been printed in The Passionate Pilgrim, although it was written by Richard Barnfield. It has connected the adjective "merry" with May for all time. In Love's Labour Lost (i. 1. 100) Biron says :

\section{"At Christmas I no more desire a rose}

Than wish a snow in May's new-fangled shows."

The last word, which is not a good reading, has been changed by some to mirth.

In I Henry $I V$. (iv. 1. 101) we have:

"As full of spirit as the month of May."

I. May day has been through many centuries full of popular celebrations, and it was only at the end of the 
nineteenth century that the frolics of Jack in the Green died out completely. The selection of a Queen of the May has, however, been partially revived in some places. Shakespeare frequently refers to the May-day and its rites-the May pole, the May dew, and the Morris dance. He also uses the "May-morn" in a metaphoric sense:

"Is in the very May morn of his youth, Ripe for exploits and mighty enterprises." Henry $V$. s. 2. 120.

The search for May dew was the first observance of the day:

"Theseus. No doubt, they rose up early to observe

The rite of May."

$M . N . D$. iv. I. 137.

Again, the porter in Henry VIII. (v. 4. 15) says:

"'Tis as much impossible

To scatter 'em as 'tis to make 'em sleep

On May-day morning."

Later in the day the morris dancers come upon the scene: "A morris for May-day" (All's Well, ii. 2. 25). Maid Marian, who is spoken of disrespectfully by Falstaff, was queen or "the lady of the May."

The first of May was also the day dedicated to St. Philip and St. James. In Measure for Measure there is a reference to this day:

"A year and a quarter old come Philip and Jacob."

The Dauphin Charles says to Joan of Arc:

iii. 2.214.

"Helen, the mother of great Constantine, Nor yet Saint Philip's daughters, were like thee."

I Henry VI. i. 2. 143.

This contains a reference to Acts of the Apostles (xxi.9): "And this same man had four daughters, virgins which did prophesy." 
June.

"He was but as the cuckoo is in June, Heard, not regarded." I Henry $I V$. iii. 2. 75.

24. Midsummer day and Midsummer eve (the latter also known as St. Jolin's eve) had their special associations with the lighting of bonfires and meetings of the Midsummer Watch. Midsummer has been supposed to be a favourable season for madness. Malvolio's absurd conduct is described by Olivia as "Very midsummer madness" (Twelfth Night, iii. 4 6r).

$$
\text { July. }
$$

"He makes a July's day short as December."

$$
\text { Winter's Tale, i. 2. 169. }
$$

The dog-days during July and part of August, named after the rising and setting of Sirius, called the dog-star, but popularly supposed to be connected with the madness of dogs.

"Twenty of the dog-days now reign."

Henry VIII. v. 5. 43.

25. St. James the Great (of Compostela). The patron saint of Spain. Helena writes to the Countess at Rousillon:

"I am Saint Jacques' pilgrim, thither gone:

Ambitious love bath so in me offended."

Alls Well, iii. 4. 4.

The next scene is at Florence, where Helena enters disguised like a pilgrim. The widow asks whither she is bound:

"Helena. To Saint Jacques le grand.

Where do the palmers lodge, I do beseech you ? "

This has puzzled the commentators, and Staunton suggests the possibility of some local Italian saint being intended, but there seems to be no reason for such a suggestion as St. James the Great is clearly referred to. Santiago de Compostela was evidently intended, although Shakespeare found it more convenient to locate this shrine 
in Italy than in Spain. The name of "San Giacomo Apostolo" was not understood by the Spanish people, who corrupted it into Compostela, which was added to the Spanish name of Saint James (Sant Jago); the place of pilgrimage being known by the united names.

26. St. Anne, mother of the Virgin Mary. Her name is twice used by Shakespeare. Sly swears by St. Anne in Taming of the Shrew as the Clown does in Twelfth Night.

August.

"You sunburn'd sicklemen, of August weary, Come hither from the furrow, and be merry."

Tempest, iv. 134 .

I. Lammas Day. Lady Capulet and the Nurse confer on the age of Juliet. Nurse asks, "How long is it now to Lammas tide?" to which question Lady Capulet answers, " A fortnight and odd days." Nurse. "Even or odd, of all days in the year, come Lammas-eve at night shall she be fourteen " (Romeo and Juliet, i. 3).

In the Roman calendar the first of August is dedicated to Faith, Hope, and Charity. Ophelia sings, "By Gis and Saint Charity" (Hamlet, iv. v. 59).

12. St. Clare, first abbess of the Poor Clares. Isabella wishes "a more strict restraint upon the sisterhood, the votarists of Saint Clare" (Measure for Measure, i. 4. 5).

24. St. Bartholonew. "Like flies at Bartholomew-tide, blind though they have their eyes " (Henry V. v. 2. 336).

The saturnalia of Bartholomew Fair at Smithfield took place at Bartholomew-tide, and one of the chief delicacies sold there was roast pig. Doll Tearsheet calls Falstaff "a little tidy Bartholomew boar pig " (2 Henry IV. ii. 4. 250).

September.

14. Holyrood Day or Holycross Day-

"On Holyrood day, the gallant Hotspur there, Young Harry Percy, and brave Archibald, That ever-valiant and approved Scot, At Holmedon met." I Henry IV. i. I. 52. 
17. St. Lambert. “At Coventry upon St Lambert's Day" (Richard II. i. i. I99).

29. Michaelmas. Simple mentions it, but blunders about the date. "Allhallowmas last, a fortnight afore Michaelmas" (Merry Wives, i. 1. 212). Theobald thought this was a misprint, and therefore proposed the change of Michaelmas to Martlemass. Johnson approved of the suggestion, but on the whole thought Shakespeare intended the blunder.

\section{October.}

25. St. Crispin and St. Crispian's Day. Ever memorable in connection with Henry V. and the battle of Agincourt :

"He that shall live this day, and see old age, Will yearly on the vigil feast his neighbours, And say 'To morrow is Saint Crispian.'

This story shall the good man teach his son;

And Crispin Crispian shall ne'er go by,

From this day to the ending of the world,

But we in it shall be remembered."

Henry $V$. iv. 3. 44 .

November.

1. Hallowmas, All Hallows and All Saints. Richard II. says of his queen :

"She came adorned hither like sweet May,

Sent back like Hallowmas or short'st of day."

$$
\text { v. } 1.78 \text {. }
$$

Speed (Two Gentlemen of Verona, ii. I. 27) uses the simile "to speak like a beggar at Hallowmas," which refers to the practice of poor people begging from house to house on this and the following day for "soul-cakes."

Prince Henry likens Falstaff to the renewal of summer in late autumn, "Farewell, thou latter spring ! farewell, All hallown summerl". (Henry IV. i. 2. 178).

2. All Soul's Day. Buckingham, when led to execution (Richard III. v. 1), asks the sheriff, "This is All Soul's day, 
fellow, is it not?" When he is answered he says, "Why, then, All Soul's day is my body's doomsday."

November II. St. Martin's Day, Martinmas, Martlemas. Joan of Arc says, "Expect Saint Martin's summer, halcyon days" (1 Henry VI. i. 2. 131).

Poins (2 Henry IV. ii. 2. I I0) catches Prince Henry's idea respecting Falstaff referred to above, and slightly alters the form, "How doth the Martlemas, your master?"

\section{December.}

Rosalind says, "Men are April when they woo, December when they wed" (As You Like It, iv. 1. 147).

"He makes a July's day short as December."

Vinter's Tale, i. 2. 169.

6. St. Nicholas, the patron of boy scholars and also of paris/2 clerks. Launce affirms that Speed was illiterate and could not read, which charge he denies, and asks to be tried. Launce answers this: "There; and Saint Nicholas be thy speed!" (Two Gentlemen, iii. I. 301).

'Highwaymen, called St. Nicholas' clerks, are alluded to in $\mathrm{I}$ Henry $I V$. ii. $\mathrm{I}$. It is supposed that this name is taken from Old Nick, the name of Satan, rather than the Christian saint.

25. Christmas Day. There is little reference to the festival in Shakespeare, but wassail is mentioned in connection with Christmas customs. How beautiful, however, are the words of Marcellus (Hamlet, i. 2) respecting the freedom from evil spirits on Christmas night:

"Some say that ever 'gainst that season comes Wherein our Saviour's birth is celebrated, This bird of dawning singeth all night long : And, then, they say no spirit dares stir abroad; The nights are wholesome; then no planets strike, No fairy takes, nor witch hath power to charm, So hallow'd and so gracious is the time." 


\section{Moveable Feasts.}

Shrove Tuesday, Ash Wednesday, Lent, Good Friday, Easter, Ascension Day and Whitsuntide all find a place in Shakespeare's works.

The Clown in All's IVell (ii. 2. 25) gives among his associated things "a pancake for Shrove Tuesday"; and Silence sings of "Merry Shrove-tide" (2 Henry IV.v. 3. 38)

Ash Wednesday is casually mentioned in the Merchant of Venice (ii. 5. 26). A "Lenten entertainment" is mentioned in Hamlet (ii. 2), and a Lenten pie in Romeo and Juliet (ii. 4). Jack-a-Lent was a stuffed puppet, and Mrs. Page addresses Robin, Falstaff's page, as "You little Jacka-Lent" (Merry Wives, iii. 3. 27). Poins says to Falstaff, "Jack, how agrees the devil and thee about thy soul, that thou soldest him on Good Friday last for cup of Madeira and a cold capon's leg ?" (1 Henry IV. i. I. 128).

The wearing of new clothes on Easter Sunday, a custom not even now extinct, is alluded to in Romeo and Juliet (iii. I. 30). Mercutio asks Benvolio if he fell out "with a tailor for wearing his new doublet before Easter."

Easter Monday was known as Black Monday in remembrance of the extreme cold on the 14th April, I 360 , when large numbers of Edward III.'s army died before Paris owing to the severe frost, a month before the Peace of Bretigny. Launcelot says, "It was not for nothing that my nose fell a-bleeding on Black Monday last" (Merchant of Venice, ii. 5. 25). There was a superstitious belief that bleeding at the nose foreboded some accident or coming event.

Ascension Day (Holy Thursday), which falls forty days after Easter Sunday, was a day of fear for King John, who asks :

"Is this Ascension Day? Did not the prophet Say that before Ascension Day at noon My crown I would give off?" 
Whitsuntide. Mrs. Quickly alludes to Wednesday in Whitsun week when she tells Falstaff that "upon Wednesday in Wheeson week... thou didst swear to me then, as I was washing thy wound, to marry me and make me my lady, thy wife?" (I Henry IV. ii. I. 96).

The Dauphin (Henry V. ii. 4, 25) refers to "a Whitsun morris dance," and Perdita says :

"Methinks I play as I have seen them do

In Whitsun pastorals." Winter's Tale, iv. 4 134.

I cannot, after some search, find the date of St. Withold's Day, mentioned in Edgar's song :

"Saint Withold footed thrice the 'old [wold];

He met the night mare and her nine-fold."

King Lear, iii. 4. 125.

The name is also spelled Swithald and Swithold, and it has been suggested that it is latinised as Vitalis, but this does not help us, as there are several saints named Vitalis, and each of these has his own particular day appointed to his memory.

H. B. Wheatley. 